\title{
Experimental study of dune vegetation impact and control on leatherback sea turtle Dermochelys coriacea nests
}

\author{
Jeremy R. Conrad ${ }^{1,2}$, Jeanette Wyneken ${ }^{1, *}$, Jeanne A. Garner ${ }^{3}$, Steve Garner $^{3}$ \\ ${ }^{1}$ Dept. of Biological Sciences, Florida Atlantic University, Boca Raton, Florida 33431-0991, USA \\ ${ }^{2}$ J.N. 'Ding' Darling National Wildlife Refuge, Sanibel, Florida 33957, USA \\ ${ }^{3}$ West Indies Marine Animal Research and Conservation Service, Inc., Frederiksted, St. Croix 00840, US Virgin Islands
}

\begin{abstract}
The leatherback sea turtle Dermochelys coriacea is a Critically Endangered species that nests on oceanic beaches. Natural disturbance cycles of erosion and accretion maintain nesting habitat on these beaches by controlling dune vegetation and sand quality. The nesting beach at Sandy Point National Wildlife Refuge in St. Croix, US Virgin Islands, is designated 'critical habitat' for leatherback turtles by the US Fish and Wildlife Service. It harbors the largest nesting population (>800 females) in the USA. It is an important rookery for Atlantic leatherback recovery efforts. For the past $30 \mathrm{yr}$, the beach has been continuously monitored and managed in order to increase hatchling recruitment and conservation. Our study highlights how a multiyear change in the natural disturbance cycle has affected dune plant growth and leatherback production at this beach. Reduced summer erosion relaxed natural control of Ipomoea pes-caprae, a native dune plant, allowing its seaward spread to cover $>75 \%$ of the nesting beach. This spread of vegetation led to both direct and indirect interactions between nesting leatherbacks and I. pes-caprae. Because the beach is managed in order to protect leatherback nests, a dune vegetation control plan was needed. We measured the effects of 3 vegetation management options on nest success: herbicide treatment, aboveground mechanical removal, and undisturbed vegetation. These treatments were compared to nest success at a non-vegetated control site. We found that the spread of I. pes-caprae reduced nesting habitat and nest productivity. Aboveground vegetation treatment did not control root growth into nests. We discuss possible vegetation management strategies to improve leatherback nesting habitat quality and maximize nest productivity while minimizing anthropogenic disturbance to the natural beach dynamics.
\end{abstract}

KEY WORDS: Nesting beach $\cdot$ Ecosystem management $\cdot$ Ipomoea pes-caprae $\cdot$ Leatherback sea turtle $\cdot$ Nest success $\cdot$ Nest ecology

\section{INTRODUCTION}

Leatherback sea turtles Dermochelys coriacea nest in tropical and sub-tropical regions worldwide. Rookeries are on open dynamic beaches that erode and accrete seasonally (Pritchard 1971, Eckert 1987, Nordmoe et al. 2004). Seasonal beach erosion and accretion cycles play a key role in maintaining the quality of the nesting environment. The cycles remove and then replace the sand between nesting seasons, effectively cleaning the sand of each year's nest debris and vegetation. High sand microbial levels from nest debris can reduce nest success (Phillott \& Parmenter 2001a). The erosion-accretion cycle also regulates pioneer plant species via salt spray and wash-over, effectively killing and removing them from the beach. Over time, this erosion pattern establishes the supralittoral vegetation boundary 
defined here as established hardwood trees such as sea grape Coccoloba uvifera and manchineel Hippomane mancinella. High rates of sand erosion lead to stand dieback (Salisbury 1952, Moreno-Casasola 1986), so the seaward spread of pioneer species such as beach morning glory Ipomoea pes-caprae is seasonally limited. Sand accretion rebuilds the dune, allowing seaward spread of pioneer species until erosion once again kills the plants (Devall \& Thien 2005). However, if the processes that drive erosion and accretion slow or change, the beach may not erode fully, leaving habitat for pioneer plant species such as I. pes-caprae to establish and spread from the supralittoral boundary toward the sea. This expansion of vegetation can degrade beach quality for nesting sea turtles, reduce nest productivity, and decrease nesting habitat.

Ipomoea pes-caprae is a pan-tropical perennial plant that colonizes sand dunes and coastal beaches from the upper boundary to the high tide line (Devall \& Thien 2005). It is native to the Caribbean and is one of the most widely distributed beach plants throughout the tropical and subtropical world (Ridley 1930, Devall \& Thien 2005). It is an aggressive, fast-growing creeper vine that spreads along the beach surface, tolerating extreme temperatures, direct sunlight, high salinity, and nutritionally impoverished soil (Devall 1992). The roots penetrate more than $1 \mathrm{~m}$ vertically into the substrate and can remain dormant even when the surface vegetation dies (Devall 1992). As a pioneer species, I. pes-caprae plays an important role in beach stabilization. Its roots anchor in the substrate, deterring erosion and allowing for secondary ecological succession by bushes and trees. However, on dynamic beaches that have consistent and extensive seasonal beach erosion cycles, erosion normally prohibits the seaward spread of I. pescaprae (Devall \& Thien 2005) and provides a beach free of vegetation for nesting sea turtles.

Beach vegetation can affect sea turtle nesting productivity by obstructing nest construction (Caldwell 1959, Bustard \& Greenham 1968, Chen et al. 2007) and potentially drying the sand, which can result in egg chamber collapse during nest excavation (Bustard \& Greenham 1968). In the Andaman Islands (India), $71 \%$ of all aborted nesting attempts by leatherbacks were in vegetated areas (Sivasundar \& Devi Prasad 1996). Vegetation can also affect developing embryos. Roots can pierce, penetrate, and desiccate eggs, erode eggshells, and encase eggs in mats of vegetation (Caldwell 1959, Ewert 1979, Lazell \& Auger 1981, Whitmore \& Dutton 1985, Leslie et al. 1996). Roots can also absorb nutrients and mois- ture from eggs (Stegmann et al. 1988, Bouchard \& Bjorndal 2000, Hannan et al. 2007). Root invasion may reduce pore spacing (air volume between sand grains), impeding gas exchange between the eggs and surrounding sand that is vital for embryonic development and survival (Ackerman et al. 1985). Roots can also affect hatchlings, as they may become entrapped in mats of roots and fail to emerge from the nest (Caldwell 1959). Those hatchlings that do emerge may become entangled or disoriented by vegetation on the beach and fail to locate the ocean (Godfrey \& Barreto 1995).

Our study was conducted at Sandy Point National Wildlife Refuge (SPNWR) on St. Croix, United States Virgin Islands (Fig. 1), an island surrounded by the Atlantic Ocean and Caribbean Sea. SPNWR supports the largest and one of the most studied nesting leatherback assemblages in the USA and northern Caribbean (Eckert 1987, Dutton et al. 2005). On September 26, 1978 the US Fish and Wildlife Service designated SPNWR as a critical habitat (US Federal Register: 43 FR 43688) for Dermochelys coriacea. SPNWR has a primary nesting beach consisting of an $800 \mathrm{~m}$ long and 10 to $20 \mathrm{~m}$ deep, usually stable, north-facing section and a shorter $600 \mathrm{~m}$ long and $50 \mathrm{~m}$ deep erosion-prone west-facing section called the erosion zone (Fig. 1). The seaward side of the primary sand dune is the turtle nesting beach; landward is a limited pioneer plant zone adjacent to tropical hardwood hammock. The major sources of natural disturbance are hurricanes and tropical storms, salt spray, and seasonal erosion and accretion. The beach typically undergoes an annual sand erosion-accretion cycle (Eckert 1987). The erosion cycle begins with the transport of sand from the west beach to the north beach during the spring and summer leatherback nesting season, and concludes with the return of sand from the north beach to the west beach during the winter, prior to the start of the next nesting season. This cyclical erosion pattern is consistent, and in most years, the west beach erodes within a few meters of the supralittoral line, preventing the spread of vegetation seaward. Nesting leatherbacks usually nest on the open beach plateau and seaward of the vegetation. Under normal conditions, nesting in vegetation at SPNWR is rare.

During 2004, the west beach failed to erode to the supralittoral boundary, while the north-facing beach decreased in vertical depth and failed to grow due to the lack of accreted sand from the west beach. This shift in the erosion cycle and growth of the west beach continued in 2005, 2006, and 2007 (Garner \& 

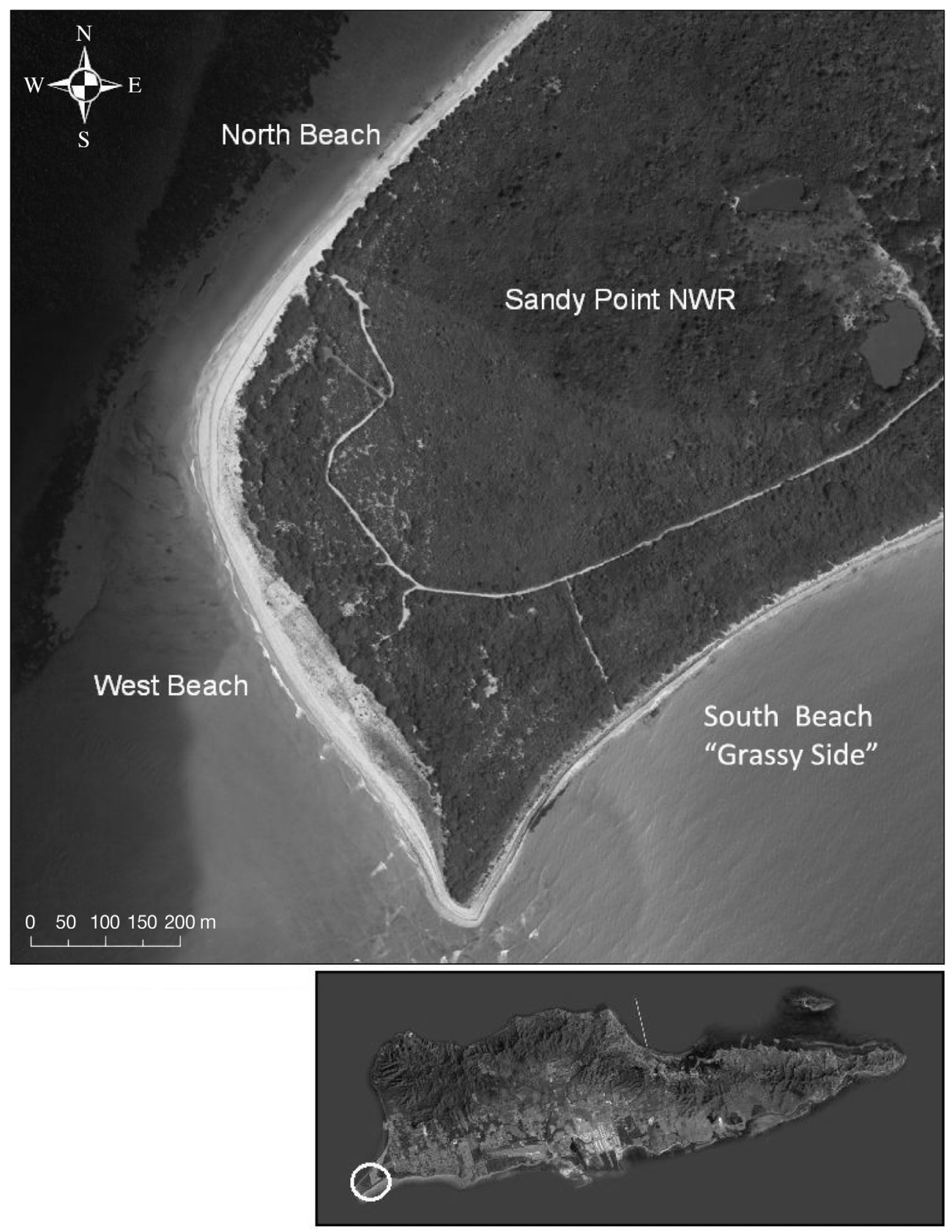

Fig. 1. St. Croix and Sandy Point National Wildlife Refuge (NWR), St. Croix, US Virgin Islands, $\left(17^{\circ} 40^{\prime} 30.96^{\prime \prime} \mathrm{N}\right.$ $64^{\circ} 54^{\prime} 01.61^{\prime \prime} \mathrm{W}$ ) which has $3.2 \mathrm{~km}$ of nesting beach. The western (west beach) and northern (north beach) typically underwent cyclically profound erosion and accretion that included sand migration between the beaches in recent record history. The spreading vegetation can be seen clearly along the west beach as the medium gray areas between the tree line and the lighter gray open dune adjacent to the water. The grassy side changed relatively little and hosts a small percentage of nests. While not the focus of this study, the total nest counts (see the supplement at www.int-res.com/articles/suppl/n015p013_ supp.pdf) include this section of beach. Map source: ESRI Imagery, Datum: D WGS84

Garner 2007), more than doubling the average west beach depth from $50 \mathrm{~m}$ in 2003 to $127 \mathrm{~m}$ in 2005 (Garner et al. 2005). This beach expansion provided substrate supporting Ipomoea pes-caprae and enabling it to spread seaward.
We describe the nesting beach that experienced change in its erosion-accretion cycle differing from its historical pattern, allowing Ipomoea pes-caprae vines to extend into the nesting area. In 2007, we experimentally examined the effects of I. pes-caprae 
on leatherback turtle nest productivity and also tested methods of vine removal to determine whether standard vegetation control techniques could enhance habitat quality for nesting turtles.

\section{MATERIALS AND METHODS}

\section{Nesting beach changes}

We mined quantitative and descriptive data from data archives for 2002 to 2006 (J. Garner \& S. Garner unpubl. data) to describe and quantify the consequences of beach change on nesting turtles, their nests, and nest relocation efforts.

\section{Vegetation coverage}

We calculated the percentage of the beach covered by Ipomoea pes-caprae in 2005 to 2007 . Beach length and width measurements were taken at the start of the nesting season and at irregular intervals during the season. Beach length was described by SPNWR fixed landmark stakes; beach widths were measured from the tree-line seaward to the outer margin of the vegetation and to the open beach high tide line.

\section{Experimental vegetation management and nest allocation}

Normally, Dermochelys coriacea prefer to nest in open beach areas and avoid vegetated beach areas. To determine how nests are affected by vegetation or vegetation removal, we had to relocate nests to experimental vegetated plots and adjacent vegetation-free control plots. We established 3 vegetation management treatments (unaltered vegetation $[\mathrm{V}]$, herbicide treated vegetation $[\mathrm{H}]$, and mechanical removal of the vegetation $[R]$, and a control treatment for plant effects on relocated leatherback nests using a randomized block design with $\mathrm{n}=10$ plots treatment $^{-1}$ in 2 blocks; Fig. 2). The treatment for each plot was randomly selected, and the $\mathrm{H}$ and $\mathrm{R}$ plots were prepared prior to the start of the leatherback nesting season. $\mathrm{V}$ plots received no form of treatment, so the $I$. pes-caprae was left in place and allowed to grow naturally. Two other blocks contained 10 control plots completely free of any vegetation (Fig. 2).

Prior to herbicide application ( $\mathrm{H}$ plots), vines on adjacent plots were separated to eliminate the sys- temic action of the herbicide on the non-herbicide plots. H plots were treated once with glyphosatebased Roundup Pro Concentrate ${ }^{\mathrm{TM}}$ diluted to a $3 \%$ working solution on a windless day. The single foliar application was completed $72 \mathrm{~d}$ (at least 2 half-lives of the active ingredient) prior to the start of the nesting season to ensure herbicide degradation before nests were relocated into the plots.

Prior to the start of nest relocations, vegetation was physically removed from the $\mathrm{R}$ and $\mathrm{H}$ plots (Fig. 3). Removal included cutting the perimeter vines with a machete, tracing each vine to the point where the

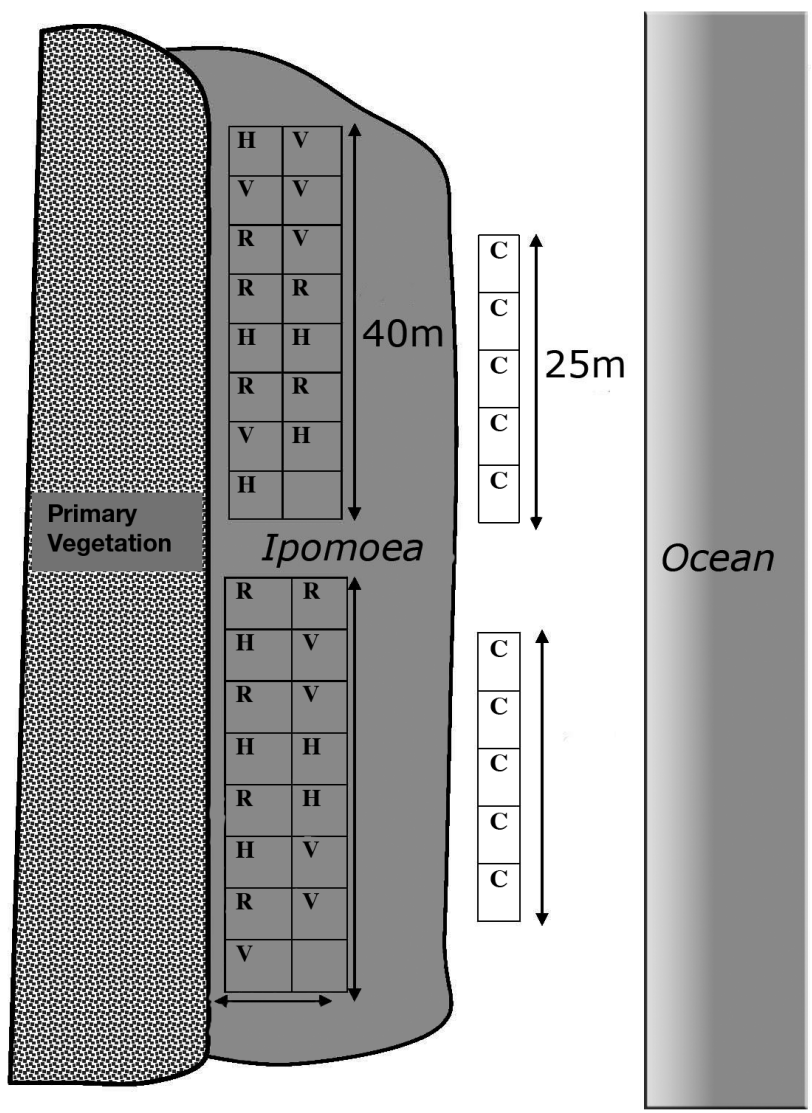

Fig. 2. Set-up of experimental and control plots on the west beach. Two blocks (40 linear $m$ of beach) contained 15 contiguous experimental plots. The 30 experimental plots (ten $5 \times 5 \mathrm{~m}$ plots treatment ${ }^{-1}$ ) were located just seaward of the primary vegetation line in areas used by Dermochelys coriacea for nesting prior to the seaward spread of Ipomoea pes-caprae. The other 2 blocks contained control plots $(\mathrm{n}=$ 10 ; five $5 \times 5 \mathrm{~m}$ plots block ${ }^{-1}$ ), completely free of any vegetation. They were located $20 \mathrm{~m}$ directly seaward of the experimental plots just beyond the $I$. pes-caprae because there was no space naturally free of vegetation in the experimental blocks region. Each $5 \times 5 \mathrm{~m}$ plot was marked by wooden stakes, placed at each corner, identifying the perimeter. $\mathrm{C}$ : control treatment, $\mathrm{H}$ : herbicidetreated vegetation, R: mechanical removal of the vegetation, V: unaltered vegetation 
stalk met the sand surface, and pulling each vine out of the plot. After removal, no vines remained above ground. The $\mathrm{H}$ and $\mathrm{R}$ plots were monitored every 2 wk to document any regrowth of vegetation. To ensure that any hatchlings emerging landward of the control plots did not become entrapped or disoriented, we physically removed the vegetation seaward of experimental blocks, thereby creating a clear path to the ocean.

In order to ensure that control (C) plots were free of vegetation before, during, and after the study, they were located directly seaward of the experimental treatments and beyond the Ipomoea pes-caprae. To prevent encroachment of the vegetation (including roots) into the control plots, a $1 \mathrm{~m}$ deep trench was dug and lined with a vertical plastic tarp between the vegetation and the control plots. The control plots and the surrounding area were also monitored biweekly throughout the season to prevent invasion by any surface vegetation.

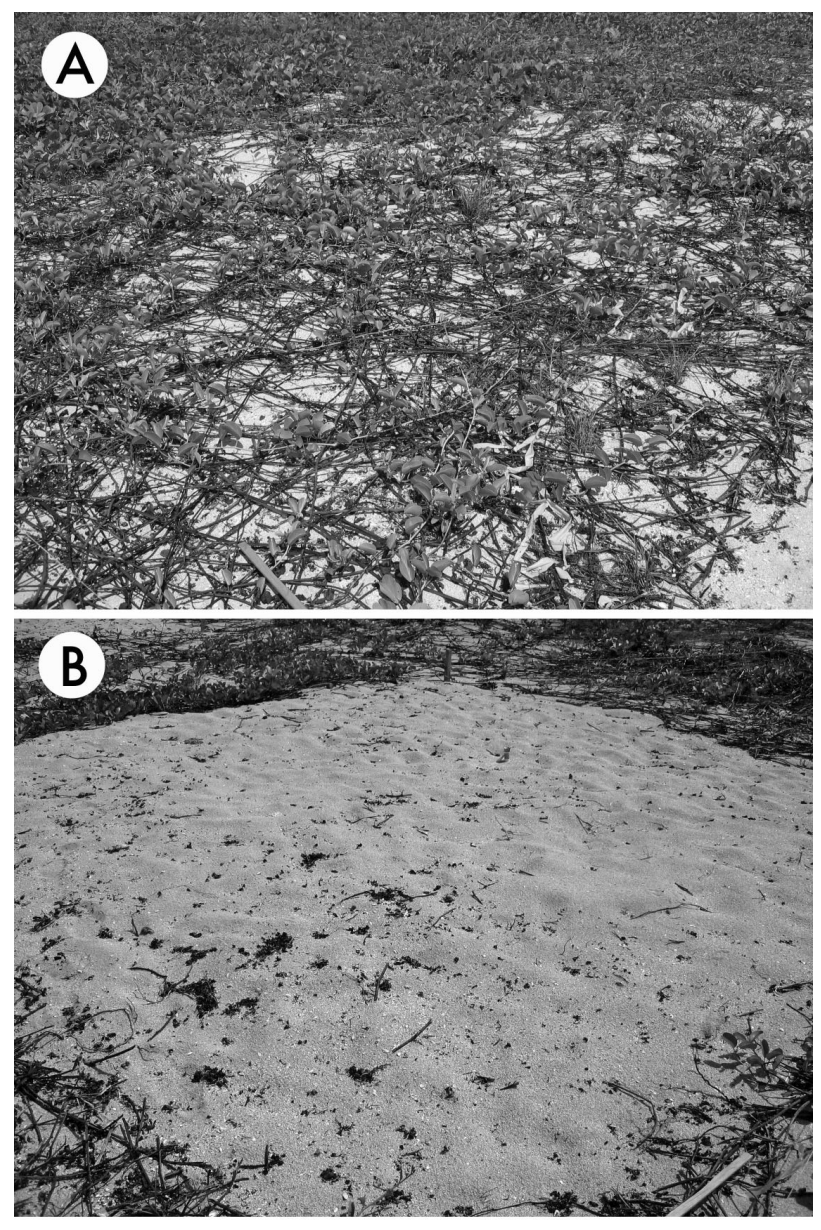

Fig. 3. Experimental plot area at Sandy Point National Wildlife Refuge (A) before and (B) after mechanical removal of vegetation (including roots) from the nesting beach
Nests relocated in the $\mathrm{V}$ plots had a $1 \mathrm{~m}$ diameter of vegetation removed from the spot of relocation just prior to nest construction to simulate a leatherback's body pit. During nest construction, any remaining roots in the $\mathrm{V}, \mathrm{R}$, and $\mathrm{H}$ nest chambers were broken to simulate the events of nest cavity construction by a leatherback.

To assess the total costs of each treatment, time in man-hours required to conduct each treatment and remove vegetation was recorded.

Eighty nests (40 plots with 2 nests plot $^{-1}$ ) were relocated to experimental plots over a 6 wk period. Clutch size was controlled by selecting nests with yolked egg counts within $1 \mathrm{SD}$ of the 2003 to 2006 SPNWR mean clutch size (77 yolked eggs). Clutch sizes ranged from 56 to 100 yolked eggs. The order in which the specific plot for each treatment received nests was selected using a random numbers table. The order was fixed $(R, H, V$, and $C)$, except for the first 2 series. Experimental nests ( $R, H, V$ in series) were relocated starting on 2 April 2007. Once the control plot root barriers were in place, control nests were added to the series $(\mathrm{R}, \mathrm{H}, \mathrm{V}$, and $\mathrm{C})$ in the third round starting on 21 April 2007. All relocated nests were in the ground by 13 May 2007, and treatments shared the same incubation period (2 April to 15 July).

Clutches of eggs (= nests) were collected from different females (marked with flipper and passive integrated transponder tags) to reduce the potential for maternal effects from any individual turtle. Clutches were only collected from individuals who successfully dug a nest and began oviposition in a doomed location (nests that would be lost to water inundation or washout prior to hatching). All nests were relocated within $3 \mathrm{~h}$ of deposition, using standard nest relocation procedures (Eckert \& Eckert 1990, Dutton et al. 1992). Nest chambers were measured before egg deposition and were similar in diameter and depth $(30 \times 70 \mathrm{~cm})$. All nests were spaced at least $1.5 \mathrm{~m}$ from each other and from the plot borders in order to minimize effects from other nests (Mortimer 1999) or adjacent plots. Once the nests were relocated, they remained undisturbed until emergence.

\section{Vegetation regrowth}

Treatment effectiveness in preventing surface regrowth was measured using a $1 \mathrm{~m}^{2}$ grid, subdivided into 100 squares of $1 \mathrm{~cm}^{2}$. The grid was positioned in each experimental plot using the water table well as a stationary landmark to standardize 
position; vegetation regrowth was assessed biweekly from the same location in each $\mathrm{H}$ and $\mathrm{R}$ plot. Photos were taken from directly above the grid. The number of grid cells containing vegetation were counted and summed as the percent cover. Control plots were monitored similarly for vegetation.

\section{Environmental characteristics in the plots}

Moisture and temperature were monitored in a subset of the treatments. One moisture probe (SSMC-005 soil moisture probe, $89 \mathrm{~mm}$ length $\times 15 \mathrm{~mm}$ width $\times 1.5 \mathrm{~mm}$ height, connected to a $\mathrm{HOBO}^{\circledR}$ Micro Station Data Logger) and 1 temperature logger (U22 Water Temp Pro temperature logger, $3.0 \mathrm{~cm}$ maximum diameter $\times 11.4 \mathrm{~cm}$ length; Onset Computer Corporation) were placed in 4 nests of each treatment $(\mathrm{n}=16)$ to monitor the nest environment during incubation. Each nest was randomly selected during the nesting season, and no plot had 2 loggers. Temperature probes were placed in the middle of the clutch. Approximately half of the eggs were placed in the nest cavity, then the temperature probe was placed, followed by the rest of the eggs. Moisture probes were placed directly above the shelled albumen gobs (SAGs = 'yolkless eggs') at the top of the nest. After probe placement, the nest was buried and tamped. Loggers were programmed to record for the duration of incubation. Temperature was measured in ${ }^{\circ} \mathrm{C} \pm 0.2$ and recorded every $30 \mathrm{~min}$. Soil moisture ([water volume divided by soil volume] \pm soil-specific calibration: $\mathrm{m}^{3}{ }_{\mathrm{H}_{2} \mathrm{O}} / \mathrm{m}^{3}$ Soil \pm 0.031 ) was recorded every $15 \mathrm{~min}$. These probes are in common use in turtle nest studies; no deleterious effects of their use on hatching or hatchling production have been found ( $\mathrm{J}$. Wyneken unpubl. data).

To monitor the location of the water table relative to the clutches, each plot held a $5 \mathrm{~cm}$ diameter PVC pipe well that extended from the surface to no less than 100 $\mathrm{cm}$ below the surface of the sand. Each well top was loosely covered. Water table measurements were taken weekly with a calibrated $2 \mathrm{~m}$ measuring stick that was inserted into the well and then removed, and the water mark was recorded. The measurement to the water mark was subtracted from the total depth of the well and indicated the water table level.

\section{Nest evaluation}

Nests were monitored for hatchling emergences starting on Day 57 of incubation. Nylon mesh $(40 \%$ shade cloth) cages $\left(15 \mathrm{~cm}\right.$ tall $\left.\times 1 \mathrm{~m}^{2}\right)$ were constructed and placed over the nests to capture emerging hatchlings and prevent them from becoming entangled or disoriented in adjacent vegetation. The cages also prevented predation on hatchlings by yellow-crowned night herons Nyctanassa violacea and feral dogs Canis familiaris. Nests were monitored hourly, and captured hatchlings were counted and released seaward of the vegetation.

Nests were excavated 1 to $3 \mathrm{~d}$ after the main emergence. Nest contents were inventoried following standard methods. Briefly, we counted unhatched and hatched eggs (by summing hatched egg shells). Unhatched eggs were opened and dead embryos were visually staged (early, middle, and late term) using broad-scale criteria, adapted from Blanck \& Sawyer (1981) and described for leatherbacks by Whitmore \& Dutton (1985). Major developmental key characteristics used in staging were evidence of a white spot formation on the eggshell and embryo morphology. Early stage (embryos <10 $\mathrm{mm}$ total length) were defined as embryos with pigmented eyes but unpigmented bodies. Middle stage (mid-term) embryos (10 to $30 \mathrm{~mm}$ in length) also were defined by size and unpigmented bodies with pigmented eyes. Lateterm embryos were pigmented and $>30 \mathrm{~mm}$ in body length. If any eggs were infertile, we did not detect them, so they would be included in early embryonic mortality. All entangled and dead hatchlings in the nest were recorded, and all live hatchlings were retrieved and released.

\section{Data analyses}

Nest inventory included calculation of mean nest hatching success (hatched egg shells/total yolked eggs) and emergence success ([hatched egg shells hatchlings in nest]/total yolked eggs) after Eckert \& Eckert (1990) as a proportion for each plot. The plot results were compared among the treatments using a 1 -way multivariate analysis of variance (MANOVA) because the 2 measures were highly correlated (Pearson's correlation 0.94). Block location (north and south blocks) and date of nest relocation in the plot were included in the MANOVA as covariates to account for spatial separation and temporal variation. Contrasts were used to assess differences between the control and each of the vegetation treatments $(\mathrm{H}$, R, V). Numbers of nests with trapped hatchlings and numbers of hatchlings trapped by roots were compared among treatments by Fisher exact tests (Zar 
1999). We calculated proportional embryonic mortality by stage for each treatment (no. dead embryos for each stage/total yolked eggs per treatment). The distribution of residuals from staged dead embryos did not meet assumptions of normality even after transformation, so the data were ranked and the normally distributed ranks were analyzed by ANOVA (SAS Institute Inc. 2004).

Environmental measurements (mean nest temperature and moisture) were analyzed separately using 1-way ANOVA and post hoc comparison tests. Data were evaluated for, and met, normality assumptions and homoscedasticity requirements. All data analyses were conducted using SAS 9.1 (SAS Institute). Surface vegetation regrowth was rare and thus was compared descriptively.

\section{RESULTS}

Leatherbacks nesting at SPNWR typically avoid nesting in vegetation; during 2004 to 2006, only $1.4 \%(11 / 809)$ of all nesting attempts on the west beach were in Ipomoea pes-caprae. Leatherbacks did not use the $75 \%$ of the west beach that was covered in vines. To avoid vegetation, leatherbacks placed their nests closer to the high tide line near the surf in the only available vine-free sand. This change increased the number of threatened nests that had to be relocated (see the supplement at www.int-res.com/articles/suppl/n015p013_supp.pdf). Even when beach erosion slowed, it did not completely cease, so nests laid near the high tide line were at risk of being washed out. In 2002 and 2003, prior to vegetative colonization, $80 \%$ (185/229) and $64 \%$ (264/413), respectively, of west beach nests were relocated. As the I. pes-caprae spread seaward, the percentage of all nests laid on the west beach that were relocated remained high, 81\% $(244 / 303)$ and $77 \%(126 / 164)$ in 2005 and 2006, respectively (see the supplement). In 2005, the threatened nests on the west beach were relocated from the high tide line to non-vegetated open sand seaward of the I. pes-caprae. The relocation of these nests illuminated another issue of vegetative overgrowth of nests and plant effects on habitat quality. We documented gross effects of vegetation on leatherback nest productivity in 2005: $6.5 \%$ (16/247) of all nests relocated on the west beach were invaded by roots. These 16 nests had lower than normal success compared with prior years (Boulon et al. 1996, Alexander et al. 2004): 25.4\% mean hatching and $24.0 \%$ mean emergence success.
The need to relocate threatened nests, even the smaller numbers in 2006, proved challenging; space for the relocated and in situ nests was limited. The north beach provided little area, as it was smaller than normal due to reduced accretion, while $75 \%$ of the west beach was covered with Ipomoea pescaprae and impacted by erosion; hence it was a shrinking beach that provided limited suitable nesting habitat (see the supplement). One consequence was a shift in the primary nest relocation beach from the north beach to the west beach. In 2002 and 2003, prior to vegetative colonization, $91 \%$ (212/233) and $83 \%(265 / 319)$ of all relocated nests were placed on the north beach. However, in 2004 to 2006, 78\% (128/165), $91 \%$ (247/272), and 62\% (98/159), respectively, of all relocated nests were placed instead on the west beach between the high tide line and the spreading I. pes-caprae (see the supplement; Alexander et al. 2004, Garner et al. 2005, 2006).

\section{Experimental nest fate}

Hatching success data were obtained from 76 of the 80 relocated experimental and control nests (see Table 2). Two control plots (4 nests) were removed from the analysis when they were inundated and/or washed out during the passage of a tropical storm. Four more control nests were included in the hatch success but excluded from calculation of emergence success because they experienced wash-out during hatchling emergence. Therefore, emergence success data were obtained from 72 of the 80 nests (12 of the 20 control nests).

\section{Hatchling production}

We compared the spatial and temporal effects data among the experimental and control blocks. There were no significant spatial (Wilks' $F_{2,31}=0.21$, p < 0.81) or temporal effects on the relocated nests (Wilks' $F_{2,31}$ $=2.30, \mathrm{p}<0.12$ ), so data from all of the nests were combined for the MANOVA. There was a significant multivariate effect of vegetation on hatchling production (hatching and emergence success) between the control and experimental plots (Wilks' $F_{6,62}=5.64$, p $<0.0001$, proportion of variance explained $=0.58$ ). Hatching and emergence success were significantly greater in the control plots than in the experimental plots (Table 1, Fig. 4). There were no significant differences in either hatching or emergence success among the $\mathrm{H}, \mathrm{R}$, and V experimental treatments (Table 1, Fig. 4). 
Table 1. Dermochelys coriacea. Models of univariate analysis of variance and post hoc comparisons among treatments. C: control treatment, $\mathrm{H}$ : herbicidetreated vegetation, $\mathrm{R}$ : mechanical removal of the vegetation, $\mathrm{V}$ : unaltered vegetation

\begin{tabular}{|lcccccc|}
\hline Source & df & SS & MS & $F$ & $p$ & Tukey-Kramer \\
\hline $\begin{array}{l}\text { Hatching success } \\
\left(\mathrm{R}^{2}=0.55\right)\end{array}$ & 5 & 5302.6 & 1060.5 & 7.96 & 0.0001 & $\begin{array}{c}\mathrm{C}>\mathrm{H}, \mathrm{R}, \mathrm{V} \\
\mathrm{p}<0.001\end{array}$ \\
$\begin{array}{l}\text { Emergence success } \\
\left(\mathrm{R}^{2}=0.46\right)\end{array}$ & 5 & 2951.5 & 590.3 & 5.46 & 0.001 & $\begin{array}{c}\mathrm{C}>\mathrm{H}, \mathrm{R}, \mathrm{V} \\
\mathrm{p}<0.001\end{array}$ \\
$\begin{array}{l}\text { Embryonic mortality } \\
\left(\mathrm{R}^{2}=0.21\right)\end{array}$ & 3 & 23154.2 & 7718.05 & 19.97 & 0.0001 & $\begin{array}{c}\mathrm{C}<\mathrm{H}, \mathrm{R}, \mathrm{V} \\
\mathrm{p}<0.001\end{array}$ \\
$\begin{array}{l}\text { Nest moisture } \\
\left(\mathrm{R}^{2}=0.14\right)\end{array}$ & 3 & 0.002 & 0.00064 & 0.56 & 0.653 & \\
$\begin{array}{l}\text { Nest temperature } \\
\left(\mathrm{R}^{2}=0.53\right)\end{array}$ & 3 & 1.03 & 0.34 & 3.76 & 0.048 & $\begin{array}{c}\mathrm{C}<\mathrm{V} \\
\mathrm{p}<0.05\end{array}$ \\
\hline
\end{tabular}

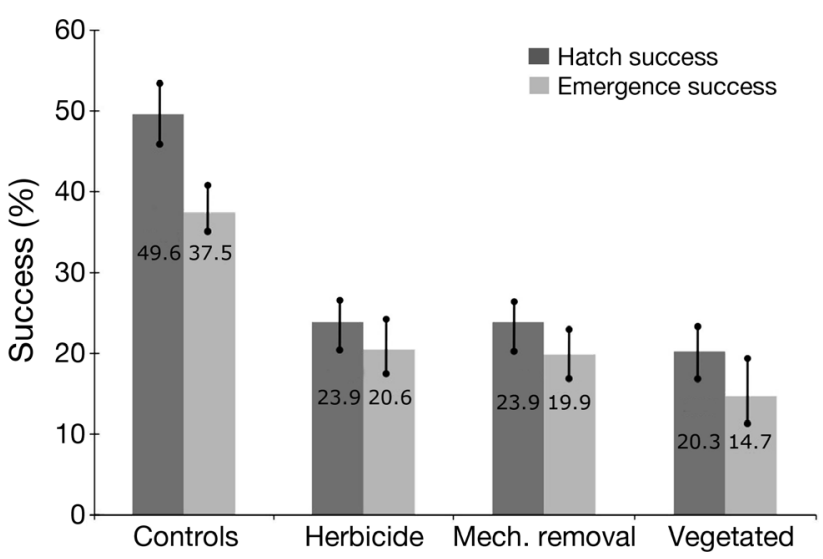

Fig. 4. Dermochelys coriacea. Percent hatching and emergence success for the experimental and control plots. Mean percentages and $95 \% \mathrm{CI}$ are shown on each bar. Nests in the herbicide, removal, and vegetated treatments did not differ from one another by either success measure, and each had lower success than the control plot nests. Details of statistical comparisons are given in Table 1

Roots trapped hatchlings in $40 \%$ of the experimental nests. There were no roots and no trapped hatchlings in the control plots (Table 2). The number of nests with trapped hatchlings dif- fered among treatments (Fisher exact test, $p=0.0007$ ). The numbers of trapped hatchlings also differed by treatment (Table 2, Fisher exact Test, $\mathrm{p}<0.0001)$. Upon excavation of the experimental nests, $4.3 \%$ of all hatchlings produced in $\mathrm{H}$ nests, $4.8 \%$ in $\mathrm{R}$ nests, and $11.5 \%$ in $\mathrm{V}$ nests were trapped in roots (Table 2).

Embryonic mortality levels were similar among all of the experimental nests and significantly higher than in the control nests (Tables 1 \& 3). $H, R$, and $V$ nests had a greater percentage of early embryonic mortality while more eggs developed to full term in $\mathrm{C}$ nests, skewing their embryonic mortality to the later stages (Table 3).

\section{Environmental factors}

The water table remained $>40 \mathrm{~cm}$ below the bottom of each clutch except for 4 nests in the $\mathrm{C}$ plots that were inundated during a storm (and omitted from our analyses). There were no significant differences in mean moisture content among the $H, R, V$, and $\mathrm{C}$ treatments (Table 1). Two of the 4 moisture probes in the control plots failed, so the analysis was based on results from 2 moisture probes in C nests and 12 moisture probes in experimental nests.

Nest temperatures (Table 4) ranged between 22.7 and $38.0^{\circ} \mathrm{C}$ during incubation. $\mathrm{V}$ nests were significantly warmer than control nests by $0.7^{\circ} \mathrm{C}$ (Table 1 ). There were no significant temperature differences among the $\mathrm{C}, \mathrm{H}$, and $\mathrm{R}$ nests. One each of the $\mathrm{R}$ and $\mathrm{H}$ temperature probes failed during incubation, so that the analysis included data from 4 temperature probes in the $\mathrm{C}$ and $\mathrm{V}$ plots and 3 temperature probes in the $\mathrm{R}$ and $\mathrm{H}$ plots.

Table 2. Dermochelys coriacea. Results of treatments with hatchlings trapped in nests by roots. Total exp.: all 3 experimental treatments. H: herbicide-treated vegetation; R: mechanical removal of the vegetation; V: unaltered vegetation; C: control

\begin{tabular}{|lcccc|}
\hline Treatment & $\begin{array}{c}\text { Nests with trapped hatchlings/ } \\
\text { nests per treatment }\end{array}$ & $\begin{array}{c}\text { Nests with trapped } \\
\text { hatchlings (\% of total) }\end{array}$ & $\begin{array}{c}\text { Total no. hatchlings } \\
\text { trapped/total no. hatched }\end{array}$ & $\begin{array}{c}\text { Hatchlings trapped } \\
\text { (\% of total) }\end{array}$ \\
\hline $\mathrm{H}$ & $7 / 20$ & 35 & $17 / 393$ & 4.3 \\
$\mathrm{R}$ & $5 / 20$ & 25 & $19 / 397$ & 4.8 \\
$\mathrm{~V}$ & $12 / 20$ & 60 & $36 / 314$ & 11.5 \\
Total exp. & $24 / 60$ & 40 & $72 / 1104$ & 6.5 \\
$\mathrm{C}$ & $0 / 16^{\mathrm{a}}$ & 0 & $0 / 674$ & 0 \\
aNests with hatch success only, see 'Materials and methods' for details & & \\
\hline
\end{tabular}


Table 3. Dermochelys coriacea. Total number of eggs (n) and proportions of embryonic mortality by stage for each treatment (no. of dead embryos for each stage/total yolked eggs [n] per treatment). Pipped embryos are those that opened the egg but did not leave the egg shell. Unpipped embryos were similar in stage but never opened the egg shell. Early mortality includes undeveloped eggs and unpigmented embryos with early pigmented eye; middle mortality includes late pigment eye and early pigment body (see 'Materials and methods: Nest evaluation' for sizes); late mortality includes late pigment body and both full-term categories. Two additional categories were scored during inventory: full-term pipped alive, and undetermined (eggs whose contents were severely degraded and could not be otherwise categorized). These last 2 categories are included for completeness but were not used in our mortality assessment

\begin{tabular}{|c|c|c|c|c|}
\hline Stage of development & $\begin{array}{c}\text { Control } \\
(\mathrm{n}=1402)\end{array}$ & $\begin{array}{l}\text { Herbicide } \\
(\mathrm{n}=1719)\end{array}$ & $\begin{array}{l}\text { Removed } \\
(\mathrm{n}=1676)\end{array}$ & $\begin{array}{l}\text { Vegetated } \\
(\mathrm{n}=1635)\end{array}$ \\
\hline \multicolumn{5}{|l|}{ Late } \\
\hline Full-term pipped (dead) & $\begin{array}{c}26.8 \\
(376 / 1402)\end{array}$ & $\begin{array}{c}11.2 \\
(193 / 1719)\end{array}$ & $\begin{array}{c}13.0 \\
(218 / 1676)\end{array}$ & $\begin{array}{c}15.1 \\
(246 / 1635)\end{array}$ \\
\hline Full-term unpipped & $\begin{array}{c}7.1 \\
(100 / 1402)\end{array}$ & $\begin{array}{c}30.1 \\
(518 / 1719)\end{array}$ & $\begin{array}{c}29.3 \\
(491 / 1676)\end{array}$ & $\begin{array}{c}33.9 \\
(555 / 1635)\end{array}$ \\
\hline Late pigment body & $\begin{array}{c}0.6 \\
(9 / 1402)\end{array}$ & $\begin{array}{c}2.7 \\
(47 / 1719)\end{array}$ & $\begin{array}{c}1.8 \\
(30 / 1676)\end{array}$ & $\begin{array}{c}2.8 \\
(45 / 1635)\end{array}$ \\
\hline \multicolumn{5}{|l|}{ Middle } \\
\hline Early pigment body & $\begin{array}{c}0.4 \\
(5 / 1402)\end{array}$ & $\begin{array}{c}3.2 \\
(55 / 1719)\end{array}$ & $\begin{array}{c}1.8 \\
(30 / 1676)\end{array}$ & $\begin{array}{c}2.8 \\
(45 / 1635)\end{array}$ \\
\hline Late pigment eye & $\begin{array}{c}0.4 \\
(6 / 1402)\end{array}$ & $\begin{array}{c}0.6 \\
(11 / 1719)\end{array}$ & $\begin{array}{c}1.9 \\
(31 / 1676)\end{array}$ & $\begin{array}{c}1.1 \\
(18 / 1635)\end{array}$ \\
\hline \multicolumn{5}{|l|}{ Early } \\
\hline Early pigment eye & $\begin{array}{c}2.0 \\
(28 / 1402)\end{array}$ & $\begin{array}{c}2.6 \\
(45 / 1719)\end{array}$ & $\begin{array}{c}5.6 \\
(93 / 1676)\end{array}$ & $\begin{array}{c}3.1 \\
(50 / 1635)\end{array}$ \\
\hline Undeveloped & $\begin{array}{c}12.1 \\
(170 / 1402)\end{array}$ & $\begin{array}{c}24.3 \\
(417 / 1719)\end{array}$ & $\begin{array}{c}20.1 \\
(337 / 1676)\end{array}$ & $\begin{array}{c}18.8 \\
(308 / 1635)\end{array}$ \\
\hline \multicolumn{5}{|l|}{ Live } \\
\hline Full-term pipped (alive) & $\begin{array}{c}0.71 \\
(10 / 1402)\end{array}$ & $\begin{array}{c}0.12 \\
(2 / 1719)\end{array}$ & $\begin{array}{c}0.12 \\
(2 / 1676)\end{array}$ & $\begin{array}{c}0.24 \\
(4 / 1635)\end{array}$ \\
\hline Undetermined & $\begin{array}{c}1.71 \\
(24 / 1402)\end{array}$ & $\begin{array}{c}2.21 \\
(38 / 1719)\end{array}$ & $\begin{array}{c}2.8 \\
(47 / 1676)\end{array}$ & $\begin{array}{c}3.06 \\
(50 / 1635)\end{array}$ \\
\hline
\end{tabular}

Table 4. Nest temperatures $\left({ }^{\circ} \mathrm{C}\right)$ for the experimental and control treatments. $\mathrm{n}$ : number of probes used in that treatment. H: herbicide-treated vegetation; R: mechanical removal of the vegetation; $\mathrm{V}$ : unaltered vegetation; $\mathrm{C}$ : control

\begin{tabular}{|lcc|}
\hline Treatment & Temperature (mean $\pm \mathrm{SD})$ & Range \\
\hline $\mathrm{C}(\mathrm{n}=4)$ & $31.7 \pm 0.2$ & $22.7-37.5$ \\
$\mathrm{H}(\mathrm{n}=3)$ & $32.3 \pm 0.1$ & $25.5-37.7$ \\
$\mathrm{R}(\mathrm{n}=3)$ & $32.2 \pm 0.6$ & $25.0-36.0$ \\
$\mathrm{~V}(\mathrm{n}=4)$ & $32.4 \pm 0.2$ & $24.6-38.0$ \\
\hline
\end{tabular}

\section{Vegetation coverage}

In 2007, vines covered $75 \%$ of the west beach at the start of the season. As the season progressed, Ipomoea pes-caprae continued to grow seaward while the beach eroded so that the proportion of the west beach covered in vines increased throughout the nesting season and the proportion of clear beach decreased. The proportional decrease in available beach was similar to that reported by Garner et al. (2006). In spite of the extensive beach vegetation, turtles arriving at SPNWR continued to nest in the progressively narrowing strip of clear beach.

\section{Vegetation regrowth}

At the beginning of the experiment, vegetation was removed from both the $\mathrm{R}$ and $\mathrm{H}$ treatments. Regrowth occurred over the subsequent 3 mo period. The $\mathrm{R}$ plots experienced regrowth over $2.4 \%$ of the standardized measured area, while the $\mathrm{H}$ plots had no surface regrowth of Ipomoea pes-caprae. However, because the standard grid sampled just $20 \%$ of each plot, it underestimated regrowth in the whole plot. Limited regrowth outside of the standard grid was recorded after the nests were excavated. Seven $\mathrm{R}$ plots and $4 \mathrm{H}$ plots had regrowth outside the standardized grid. Regrowth outside the grid averaged $10 \%$ of the area in the $\mathrm{R}$ plots and $4 \%$ in $\mathrm{H}$ plots. All vegetated treatments $(H, R, V)$ had root growth, which was found upon nest inventory. Roots and rootlets grew and invaded the nest chamber even though all roots in the nest were broken during nest relocation. None of the control nests had roots.

\section{Comparisons of effort for each vegetation treatment}

Herbicide application for $250 \mathrm{~m}^{2}$ required 3 manhours $\left(83.3 \mathrm{~m}^{2} \mathrm{~h}^{-1}\right)$; removal of dead vegetation added 10 man-hours $\left(25 \mathrm{~m}^{2} \mathrm{~h}^{-1}\right)$, totaling 13 manhours plus herbicide costs. Mechanical removal of the vine from the experimental plots required 10 man-hours of labor $\left(25 \mathrm{~m}^{2} \mathrm{~h}^{-1}\right)$. Both the $\mathrm{R}$ and $\mathrm{H}$ plots experienced regrowth of surface vegetation, requiring an additional 2 man-hours of labor. 


\section{DISCUSSION}

Under typical conditions, seasonal beach erosion occurs due to currents, storms, and wind (Schwartz 2005). On sea turtle nesting beaches, this erosion cleanses the sand of bacteria and nest debris, and limits the seaward spread of vegetation. However, when weather patterns shift, the rates of erosion can change (Schwartz 2005). When erosion rates relaxed at SPNWR, Ipomoea pes-caprae spread seaward to the high tide line, compromising the quality and availability of clear beach both used by the turtles (in situ nests) and needed for nest relocations.

In controlled experiments, we found that Ipomoea pes-caprae decreased nest productivity by reducing leatherback hatching and emergence success rates. We also found that I. pes-caprae is an aggressive vine and is difficult to control either by a single treatment of herbicide or mechanical removal. Neither method effectively restored the beach as a high-quality nesting site for Dermochelys coriacea in the absence of significant erosion and accretion cycling.

\section{Reduction of suitable habitat}

The change in the seasonal erosion-accretion cycle reduced north beach accretion and led to subsequent expansion and stabilization of the west beach by Ipomoea pes-caprae, which significantly reduced suitable nesting habitat for leatherback turtles. I. pes-caprae covered $75 \%$ of the west beach and rendered the beach useless for leatherback nesting. Unlike green turtles Chelonia mydas (Whitmore \& Dutton 1985) and hawksbill turtles Eretmochelys imbricata (Kamel \& Mrosovsky 2005), which are known to nest in vegetation, leatherbacks prefer to nest on open sandy beaches that are free of vegetation and debris (Pritchard 1971, Whitmore \& Dutton 1985, Leslie et al. 1996). As the I. pes-caprae spread seaward, the leatherbacks continued to nest but did so closer to the high tide line and the vegetation line. Such nest placement put the clutches at risk so that nest relocation efforts increased.

As a result of the increase in relocated nests, total nesting effort productivity, defined here as the total number of hatchlings produced for all nests in a season, likely suffered. While the relocation of nests from at-risk locations to safer sites on the beach is a critical component of the SPNWR sea turtle conservation plan for maximizing leatherback productivity (Dutton et al. 2005), hatching and emergence success are significantly lower in relo- cated nests compared to in situ nests at SPNWR (Garner et al. 2005, 2006).

The north beach was also impacted by the change in the erosion-accretion cycle. Due to reduced erosion on the west beach and associated lack of accretion on the north beach, turtles reduced their north beach nesting effort over a $4 \mathrm{yr}$ period. In 2002 and 2003, 39 to $44 \%$ of all nests laid remained in situ on the north beach; during 2004 to 2006, just 28, 28, and $31 \%$ of nests, respectively, occurred there (Table S1 in the supplement).

The shift in the primary relocation beach, from the north beach to the west beach, increased nest density on the shrinking west beach. High nest density can result in selection of suboptimal nest sites and can increase the risks of accidental excavation of incubating nests by nesting turtles, increase competition among nests for oxygen and moisture, and increase microbial levels in the sand. Decreased hatching success and poor hatchling performance are also linked to high nest density (Girondot et al. 2002, Caut et al. 2006a).

\section{Hatchling production and vegetation control treatments}

Hatch and emergence success were significantly higher in the control nests than in the vegetated or non-vegetated experimental nests (Fig. 4, Tables 1 $\& 2$ ). This difference was due to the extensive root systems found in all 60 nests relocated to the experimental sites. Roots from Ipomoea pes-caprae remained alive, invaded nests, and often penetrated and enveloped eggs, leaving them desiccated and devoid of yolk and albumen (Fig. 5).

Root invasion of turtle eggs has been observed in nests of freshwater (Ewert 1979), estuarine (Lazell \& Auger 1981, Stegmann et al. 1988), and marine (Caldwell 1959, Whitmore \& Dutton 1985, Bouchard \& Bjorndal 2000, Hannan et al. 2007) turtle species. Across its range, Ipomoea pes-caprae is known to destroy turtle nests including those of flatbacks Natator depressus in northwestern and northeastern Australia (A. Stevens pers. comm., J. Wyneken unpubl. data), Kemp's ridleys Lepidochelys kempii in eastern Mexico (Eich 2009), and loggerheads Caretta caretta in Florida, USA (J. Wyneken unpubl. data). Extensive roots also entangle hatchlings in their nests (Caldwell 1959), resulting in death. However, some sea turtles successfully nest in vegetation (hawksbill turtles Eretmochelys imbricata, Kamel \& Delcroix 2009; and some green turtles Chelonia mydas, Whit- 


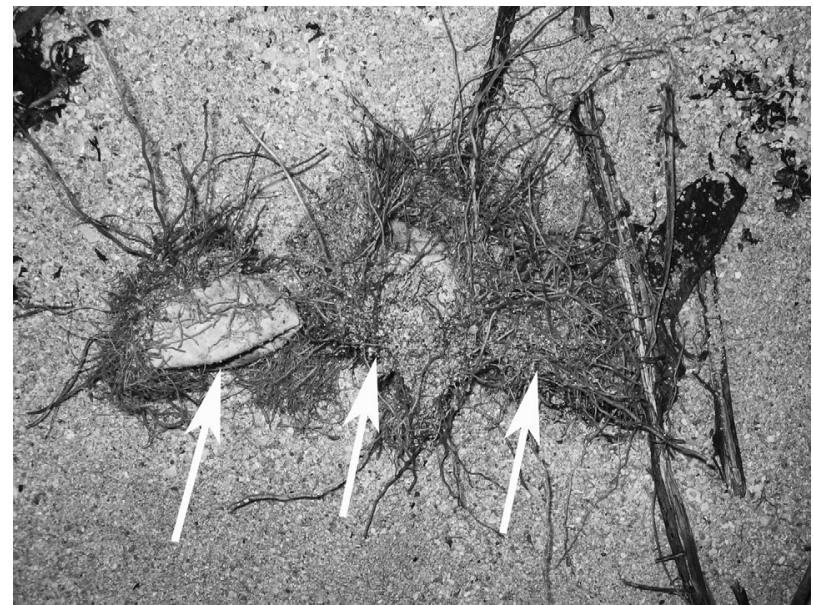

Fig. 5. Dermochelys coriacea. Three leatherback turtle eggs (arrows) excavated from a vegetated plot invaded by Ipomoea pescaprae roots. These eggs did not hatch

more \& Dutton 1985), suggesting there may be species-specific differences in vulnerability. It is unclear why hawksbill and some green turtle eggs and hatchlings are able to escape roots.

The similarities in hatching and emergence success among the 3 vegetated treatments (Fig. 4) suggest that our vegetation control methods were ineffective in reducing the impacts of Ipomoea pescaprae on leatherback nests. While the aboveground vegetation was limited in the $\mathrm{H}$ and $\mathrm{R}$ plots, neither herbicide nor mechanical removal treatments were successful in killing the extensive root system. Both $\mathrm{H}$ and $\mathrm{R}$ nests experienced root invasion and low productivity (Fig. 4). The glyphosate-based herbicide used in the $\mathrm{H}$ treatment is a systemic poison that was selected to attack both the above-ground plant and its root system. However, a single foliar application prior to the start of the experiment may not have been sufficient to kill all roots. This restricted use was necessary to accommodate other conservation goals in the refuge.

There are at least 2 alternative explanations for continued root growth and invasion in the $\mathrm{R}$ and $\mathrm{H}$ treatments. First, the small scale $(5 \times 5 \mathrm{~m})$ of the experimental plots may not have provided a sufficient buffer for nests to escape root systems from adjacent non-treated vegetation. Prior to administering the $\mathrm{R}$ and $\mathrm{H}$ treatments, we cut the vegetation at the borders of the $\mathrm{R}$ and $\mathrm{H}$ plots to avoid confounding effects. We then removed the live and dead surface vegetation in the $\mathrm{R}$ plots and dead vegetation (after herbicide application) in $\mathrm{H}$ plots. The only roots that we removed were those pulled out with the surface vegetation. We did not measure or control for live roots remaining in, or growing into, the $\mathrm{H}$ and $\mathrm{R}$ plots from outside their borders.

Secondly, existing roots that are not physically removed and remain associated with a live plant may grow and envelop eggs or entangle and trap hatchlings. Root growth in dune plants can be rapid and extensive (Barnett \& Crewz 1997). Therefore, aboveground clearing may not have adequately addressed the below-ground root threat. It was beyond the scope of this study to trace all root origins, so the problem roots may have originated from untreated plants in nearby $\mathrm{V}$ plots or from outside the study area.

None of the experimental treatments led to improved emergence success because most roots underground, whether dormant, from adjacent areas, or dead but intact, were not removed. Remaining roots entangled or trapped hatchlings during emergence in all 3 vegetated treatments (Table 2). As a result, any leatherback nest placed in a plot that contained roots or that was invaded by roots suffered significant loss.

When compared to control plots, eggs in all vegetated treatments $(\mathrm{H}, \mathrm{R}, \mathrm{V})$ suffered greater embryonic mortality throughout development (Table 3). While this study did not experimentally address why developing embryos died, we noted that the experimental nests had significantly greater earlystage and full-term unpipped mortality in the presence of root masses. During the 2 mo incubation period, the roots formed mats that encased and pierced many eggs (Fig. 5). If roots pierce the eggshell, not only do they have access to the nutrients, but they also create access for microbial invasion. Once roots encase an egg, they effectively reduce the available surface for gas and moisture exchange. Sufficient surface area is important for embryo survival, particularly at later stages when embryonic metabolism is greatest (Ackerman 1997, Phillott \& Parmenter 2001b). Both encasement and piercing can stop development quickly. At nest inventory, we found embryos as young as $12 \mathrm{~d}$ of age when roots had compromised eggshell integrity. Earlier mortality is difficult to identify when decomposition or desiccation occurs. In the control plots, where no roots occurred, more embryos developed to full term and either successfully hatched and emerged or died during pipping.

The lack of a difference in hatching success or embryonic mortality among the $\mathrm{H}, \mathrm{R}$, and $\mathrm{V}$ treatments (Table 1) suggests that the herbicide, as applied, did not adversely affect the developing eggs. 
Above-ground foliage reduced leatherback hatchling survival. While we placed restraining cages above the nests to collect emerging hatchlings, some emerged outside the cages and became entangled. Additionally, hatchlings from natural nests that were not a part of the study were observed trapped in the Ipomoea pes-caprae; they were freed and released.

\section{Environmental factors}

Nest temperature is a function of beach temperature due to solar radiation and metabolic heat produced by developing embryos (Ackerman 1997). Even though the control nests had significantly more full-term developing embryos, they were the coolest of all nests. Vegetated nests were warmer than the control nests (Table 4). Because we controlled nest size, shape, depth, and location, differences in temperatures likely were related to the presence of the vegetation. We speculate that the higher nest temperatures in the vegetated plots may be the result of the low albedo (lower solar reflectance) of Ipomoea pes-caprae when compared to the high albedo of the surrounding light-colored sands. Within the scope of our study, we could not rule out whether added warmth could be attributed to live or decaying roots.

The significant difference in mean nest temperatures between the $\mathrm{V}$ and $\mathrm{C}$ plots was not large: $0.7^{\circ} \mathrm{C}$ (Tables $1 \& 4$ ). While it was beyond the scope of this study to determine how this relatively small temperature difference might have affected the experimental nests, we do know that thermal factors are important in sea turtle nests. Developmental rates are directly related to temperature (Miller \& Limpus 1981), sex determination is temperature dependent (a $1.0^{\circ} \mathrm{C}$ difference may result in all male or all female leatherback nests; Rimblot et al. 1985, Mrosovsky 1994, Binckley et al. 1998), and both yolk utilization and hatchling size are influenced by incubation temperature (Packard et al. 1987, Packard \& Packard 1988, Booth \& Astill 2001).

Vegetation draws moisture from the sand; therefore, we expected reduced moisture levels in the vegetated nests. However, we detected no difference in moisture content among the vegetated and control treatments. The lack of difference may be attributed to the placement of the probes in the nest. The moisture probes were located on top of the uppermost eggs and SAGs and were covered with sand. The SAGs may have buffered the ability of the probes to detect dehydration elsewhere, as SAGs can act as a moisture source (Caut et al. 2006b).

\section{Comparisons of effort for each vegetation treatment}

The effort comparison between the $H$ and $R$ treatments included their initial treatment and removal of any regrowth of vegetation after the treatment. We anticipated that after the initial $\mathrm{H}$ and $\mathrm{R}$ treatments, the $\mathrm{H}$ treatment would be more efficient and cost effective because it was expected that the herbicide would be effective in killing and preventing regrowth of vegetation. However, the herbicide did not prevent vegetation regrowth, so some plots required additional removal. When factoring in time and labor of the initial treatment and removal, plus removal of regrowth for the $\mathrm{H}$ treatment, the herbicide treatment required more effort in man-hours per $\mathrm{m}^{2}$ than did the mechanical removal treatment.

\section{Conservation and management}

Tropical seaward beach dunes are dynamic ecosystems that are driven, in part, by the natural disturbance of the sand erosion-accretion cycle. This cycle can benefit leatherback turtle productivity by effectively cleansing the sand of the previous season's roots, vines, and old nest debris as well as maintaining an open beach with a vegetation boundary. However, high erosion can threaten productivity by washing out incubating nests on an unstable beach. While these processes are natural, prolonged stabilization of the beach had adverse impacts on leatherback hatchling production. Managing to protect an endangered species within the context of the ecosystem is challenging because of large differences in the life history characteristics of the turtles (long-lived, late-maturing, low reproductive success) and dune plants (short lived, rapidly maturing with high reproductive output). Undesired effects may arise if managing an entire ecosystem to enhance one species, yet conservation management solutions may be forced to accommodate at-risk species at the expense of other species that are not depleted.

Ipomoea pes-caprae is globally abundant and distributed throughout tropical and subtropical beaches, across 5 continents (Ridley 1930, Devall \& Thien 2005). It is an important native plant to the US Virgin Islands because it may promote beach stability and ecological succession. However, when left unchecked, this plant can reduce suitable nesting habitat for turtles, impede nesting, and reduce nest productivity (Whitmore \& Dutton 1985, present 
study). SPNWR is designated as critical habitat for leatherback turtles, which are listed as endangered under the US Endangered Species Act of 1973 as amended through the 100th Congress (P.L. 100-478, October 7,1988$)$, and they are considered Critically Endangered worldwide (IUCN Red List, see Sarti Martinez 2000).

Due to SPNWR's critical habitat designation for Dermochelys coriacea, the management priority is to protect the beach environment as prime nesting habitat. While the St. Croix population is small but stable or slightly increasing (TEWG 2007), it is not yet a candidate for a status change or removal from the protected species list. Additionally, strong protection of the nests through relocation and nesting beach protection are major factors in the population's increase (Dutton et al. 2005). Thus, management to maximize hatchling production while maintaining the natural ecosystem processes remains a priority. Our study identified that focused vegetation management may be necessary.

More broadly, our results suggest that leatherback nests laid in or near vegetation should be considered at risk and possibly relocated. Additionally, because neither mechanical removal nor herbicidal treatments was successful in managing Ipomoea pes-caprae roots, additional techniques should be used when the vine must be controlled. We speculate that when its seaward spread on nesting beaches is large and nest relocation is necessary, small sections may be cleared of surface vegetation and roots completely removed to create small nest relocation sites. Based on our assessments, we anticipate that mechanical removal of the vegetation, including a complete removal of the roots and seeds (excavation and sifting) combined with placement of a physical root barrier along the 'walls' of a prepared plot to prevent the encroachment of roots from adjacent vegetation, might be effective. This option, while untested, leaves most of the ecosystem unaltered to function naturally, but still may address the turtle conservation goals through the creation of root-free relocation plots. Establishing such plots would require significant investments in time, effort, and equipment. However, once in place, maintenance to remove any vegetation encroachment should be minimal if performed regularly.

To maintain sand quality across seasons and years, relocated nests could be placed in half of each plot each season. The half used in a season should be left dormant during the following season to allow the used sand to 'recover' from nest bacterial loads and decaying organic material (Phillott \& Parmenter 2001a) before being used again.
Ideally, site management should include monitoring of shoreline change over time, including the vegetation extent and beach depth. If the natural (baseline) disturbance (erosion-accretion) cycle resumes, it can control the spread of vegetation, and special nest relocation plots can be eliminated.

At sea turtle nesting beaches that do not use nest relocation as a management tool or that are not primarily leatherback nesting beaches, the above approaches may be of limited utility. For example, nesting preferences of other sea turtle species may not require vegetation management. The potential techniques we suggest may have their greatest value when population numbers are low or declining and there is expectation that short-term alterations are likely to enhance the population.

Acknowledgements. We thank N. Dorn, D. Gawlik, K. Mansfield, C.E. Proffitt, M. Salmon, and J. Volin for thoughtful discussions. M. Evans and C. Lombard from the US Fish \& Wildlife Service (USFWS) and W. Coles (USVI DPNR) assisted with permitting and provided supplies and equipment for this study. B. Yoshioka (USFWS Coastal Program) facilitated funding for this project. The project would not have been possible without the 2006-2007 West Indies Marine Animal Research and Conservation Service (WIMARCS) staff, K. Garrett, J. Gless, C. Smith, and E. Weston. We thank A. Woodson, the Youth Conservation Core (YCC) group, and M. Gibbs and her students who assisted in vegetation removal. E. Conrad assisted with many aspects of the project. These studies were conducted in accordance with FAU IACUC guidelines for the use of animals in research. The USFWS funded and permitted this study through cooperative agreement 401816J084 to WIMARCS; additional support was provided by WIMARCS and personal funds.

\section{LITERATURE CITED}

Ackerman RA (1997) The nest environment and embryonic development of sea turtles. In: Lutz PL, Musick JA (eds) The biology of sea turtles. CRC Press, Boca Raton, FL, p 83-106

Ackerman RA, Seagrave RC, Dmi'El R, Ar A (1985) Water and heat exchange between parchment-shelled reptile eggs and their surroundings. Copeia 1985:703-711

Alexander JL, Garrett KL, Garner SA, Conrad J, Coles W (2004) Tagging and nesting research of leatherback sea turtles (Dermochelys coriacea) on Sandy Point, St. Croix, U.S. Virgin Islands, 2004. WIMARCS publication to USFWS. Available at: www.wimarcs.org/download/2004 FinalReport_SPNWR.pdf (accessed 24 Sep 2011)

Barnett MR, Crewz DW (1997) Common coastal plants in Florida. A guide to planting and maintenance. Florida Sea Grant FLSGP-H-97-001. University Press of Florida, Gainesville, FL

Binckley CA, Spotila JR, Wilson KS, Paladino FV (1998) Sex determination and sex ratios of Pacific leatherback turtles, Dermochelys coriacea. Copeia 1998:291-300 
Blanck CE, Sawyer RH (1981) Hatchery practices in relation to early embryology of the loggerhead sea turtle, Caretta caretta (Linné). J Exp Mar Biol Ecol 49:163-177

Booth DT, Astill K (2001) Incubation temperature, energy expenditure and hatchling size in the green turtle (Chelonia mydas), a species with temperature-sensitive sex determination. Aust J Zool 49:389-396

- Bouchard SS, Bjorndal KA (2000) Sea turtles as biological transporters of nutrients and energy from marine to terrestrial ecosystems. Ecology 81:2305-2313

Boulon RH Jr, Dutton PH, McDonald DL (1996) Leatherback turtles (Dermochelys coriacea) on St. Croix, U.S. Virgin Islands: fifteen years of conservation. Chelonian Conserv Biol 2:141-147

> Bustard RH, Greenham P (1968) Physical and chemical factors affecting hatching in the green sea turtle, Chelonia mydas. Ecology 49:269-276

Caldwell DK (1959) The loggerhead turtles of Cape Romain, South Carolina. Bull Fla State Mus Biol Sci 4:319-348

> Caut S, Hulin V, Girondot M (2006a) Impact of densitydependent nest destruction on emergence success of Guianan leatherback turtles (Dermochelys coriacea). Anim Conserv 9:189-197

Caut S, Guirlet VE, Jourquet P, Girondot M (2006b) Influence of nest location and yolkless eggs on the hatching success of leatherback turtle clutches in French Guiana. Can J Zool 84:908-915

> Chen HC, Cheng IJ, Hong E (2007) The influence of the beach environment on the digging success and nest site distribution of the green turtle, Chelonia mydas, on Wanan Island, Penghu Archipelago, Taiwan. J Coast Res 23: 1277-1286

Devall MS (1992) The biological flora of coastal dunes and wetlands. 2. Ipomoea pes-caprea (L.) Roth. J Coast Res 8: 442-456

> Devall MS, Thien LB (2005) Inland occurrence of the strand plant Ipomoea pes-caprae (Convolvulaceae) around Lake Nicaragua. Southwest Nat 50:380-384

Dutton PH, McDonald DL, Boulon RH Jr (1992) Tagging and nesting research of leatherback sea turtles (Dermochelys coriacea) on Sandy Point, St. Croix, U.S. Virgin Islands, 1992. US Fish and Wildlife Publication, Available at: http://fw.dpnr.gov.vi/education/EndSpecies/Leatherback/ 1992_DcReport.pdf (accessed 24 Sep 2011)

Dutton DL, Dutton PH, Chaloupka M, Boulon RH (2005) Increase of a Caribbean leatherback turtle Dermochelys coriacea nesting population linked to long-term nest protection. Biol Conserv 126:186-194

Eckert KL (1987) Environmental unpredictability and leatherback sea turtle (Dermochelys coriacea) nest loss. Herpetologica 43:315-323

Eckert KL, Eckert SA (1990) Embryo mortality and hatch success in in situ and translocated leatherback sea turtle Dermochelys coriacea eggs. Biol Conserv 53: $37-46$

Eich AML (2009) Evolutionary and conservation implications of sex determination and hatchling depredation in Kemp's ridley sea turtles. PhD dissertation, The University of Alabama at Birmingham, AL

Ewert MA (1979) The embryo and its egg: development and natural history. In: Harless M, Morlock H (eds) Turtles: perspectives and research. John Wiley \& Sons, New York, NY, p 333-413

Garner JA, Garner SA (2007) Tagging and nesting research on leatherback sea turtles (Dermochelys coriacea) on
Sandy Point, St. Croix, U.S. Virgin Islands, 2007. WIMARCS Publication to USFWS. Available at: www. wimarcs.org/resourceList.htm (accessed 24 Sep 2011)

Garner JA, Garner SA, Coles W (2005) Tagging and nesting research of leatherback sea turtles (Dermochelys coriacea) on Sandy Point, St. Croix, U.S. Virgin Islands, 2005. WIMARCS Publication to USFWS. Available at: www.wimarcs.org/download/2005FinalReport_SPNWR. pdf (accessed 24 Sep 2011)

Garner JA, Garner SA, Coles W (2006) Tagging and nesting research of leatherback sea turtles (Dermochelys coriacea) on Sandy Point, St. Croix, U.S. Virgin Islands, 2006. WIMARCS Publication to USFWS. Available at: www.wimarcs.org/download/2006FinalReport_SPNWR. pdf (accessed 24 Sep 2011)

Girondot M, Tucker AD, Rivalan P, Godfrey MH, Chevalier J (2002) Density-dependent nest destruction and population fluctuations of Guianan leatherback turtles. Anim Conserv 5:75-84

Godfrey MH, Barreto R (1995) Beach vegetation and sea finding orientation of turtle hatchlings. Biol Conserv 74:29-32

> Hannan LB, Roth JD, Ehrhart LM, Weishampel JF (2007) Dune vegetation fertilization by nesting sea turtles. Ecology 88:1053-1058

Kamel SJ, Delcroix E (2009) Nesting ecology of hawksbill turtle, Eretmochelys imbricata, in Guadeloupe, French West Indies from 2000-07. J Herpetol 43(3):367-376

Kamel SJ, Mrosovsky N (2005) Repeatability of nesting preferences in the hawksbill sea turtle, Eretmochelys imbricata, and their fitness consequences. Anim Behav 70: $819-828$

> Lazell JD, Auger PJ (1981) Predation on diamondback terrapin (Malaclemys terrapin) eggs by dune grass (Ammophila breviligulata). Copeia 723-724

Leslie AJ, Penick DN, Spotila JR, Paladino FV (1996) Leatherback turtle, Dermochelys coriacea, nesting and nest success at Tortuguero, Costa Rica in 1990-91. Chelonian Conserv Biol 2:159-168

Miller JD, Limpus CJ (1981) (Banks CB, Martin AA eds) Incubation period and sexual differentiation in the green turtle Chelonia mydas L. Proc Melbourne Herp Symp. Zoological Board of Victoria, Melbourne, p 66-73

- Moreno-Casasola P (1986) Sand movement as a factor in the distribution of plant communities in a coastal dune system. Vegetatio 65:67-76

Mortimer JA (1999) Reducing threats to eggs and hatchlings: hatcheries. In: Eckert KL, Bjorndal KA, AbreuGrobois FA, Donnelly M (eds) Research and management techniques for the conservation of sea turtles. IUCN/SSC Marine Turtle Specialist Group Publ. No. 4, Washington, DC, p 175-178

Mrosovsky N (1994) Sex ratios of sea turtles. J Exp Zool 270: $16-27$

Nordmoe ED, Sieg AE, Sotherland PR, Spotila JR, Paladino FV, Reina RD (2004) Nest site fidelity of leatherback turtles at Playa Grande, Costa Rica. Anim Behav 68: 387-394

Packard GC, Packard MJ (1988) Physiological ecology of reptilian eggs and embryos. In: Gans C, Huey RB (eds) Biology of reptilia, Vol 16. Alan R. Liss, New York, NY, p 523-605

Packard GC, Packard MJ, Miller K, Boardman TJ (1987) Influence of moisture, temperature and substrate on snapping turtle eggs and embryos. Ecology 68: 983-993 
Phillott AD, Parmenter CJ (2001a) The distribution of failed eggs and the appearance of fungi in artificial nests of green (Chelonia mydas) and loggerhead (Caretta caretta) sea turtles. Aust J Zool 49:713-718

Phillott AD, Parmenter CJ (2001b) Influence of diminished respiratory surface area on survival of sea turtle embryos. J Exp Zool 289:317-321

Pritchard PCH (1971) The leatherback or leathery turtle, Dermochelys coriacea. IUCN Monogr 1:1-39

Ridley HN (1930) The dispersal of plants throughout the world. L. Reeve and Co., Ashford

Rimblot F, Fretey J, Mrosovsky N, Lescure J, Pieau C (1985) Sexual differentiation as a function of the incubation temperature of eggs in the sea-turtle Dermochelys coriacea (Vandelli, 1761). Amphib-Reptilia 6:83-92

Salisbury EJ (1952) Downs \& dunes: their plant life and its environment. G. Bell \& Sons, London

Sarti Martinez AL (2000) Dermochelys coriacea. In: IUCN 2011. 2011 IUCN Red List of Threatened Species Version 2011.1. Available at www.iucnredlist.org/apps/redlist/

Editorial responsibility: Matthew Godfrey,

Beaufort, North Carolina, USA details/6494/0 (accessed 24 Sep 2011)

SAS Institute (2004) SAS/STAT ${ }^{\circledR}$ 9.1. User's guide. SAS Institute, Cary, NC

Schwartz ML (2005) Encyclopedia of coastal science. Springer, Dordrecht

Sivasundar A, Devi Prasad KV (1996) Placement and predation of nests in leatherback sea turtles in the Andaman Islands, India. Hamadryad 21:36-42

Stegmann EW, Primack RB, Ellmore GS (1988) Absorption of nutrient exudates from terrapin eggs by roots of Ammophila breviligulata (Gramineae). Can J Bot 66: 714-718

Turtle Expert Working Group (TEWG) (2007) An assessment of the leatherback turtle population in the Atlantic Ocean. NOAA Tech Memo NMFS-SEFSC-555, Miami, FL

Whitmore CP, Dutton PH (1985) Infertility, embryonic mortality, and nest-site selection in leatherback and green sea turtles in Suriname. Biol Conserv 34:251-272

Zar J (1999) Biostatistical analysis. Prentice Hall, Englewood Cliffs, NJ

Submitted: March 22, 2010; Accepted: June 13, 2011

Proofs received from author(s): September 27, 2011 